\title{
MULTICRITERIA APPROACH TO THE SELECTION OF THE TRAINING MODEL OF DANGEROUS GOODS TRANSPORT ADVISORS IN THE MINISTRY OF DEFENSE AND THE SERBIAN ARMY
}

\author{
Vesko M. Lukovaca, Svetlana R. Zeljić Drakulićb, \\ Lazar M. Tomićc, Feng Liu ${ }^{d}$ \\ a University of Defence in Belgrade, Military Academy, \\ Department of Logistics, Belgrade, Republic of Serbia, \\ e-mail: lukovacvesko@yahoo.com, corresponding author, \\ ORCID iD: (ibttps://orcid.org/0000-0002-9104-0184 \\ b Serbian Armed Forces, Land Army, Training Command, \\ Belgrade, Republic of Serbia, \\ e-mail: cecazeljic@gmail.com, \\ ORCID iD: (Dhttps://orcid.org/0000-0003-2301-7289 \\ c Serbian Armed Forces, Land Army, 3rd Brigade, \\ Niš, Republic of Serbia, \\ e-mail: tomiclazar17@gmail.com, \\ ORCID iD: (i)https://orcid.org/0000-0003-3818-125X \\ d Zhejiang Wanli University, Business School, Ningbo, \\ People's Republic of China, \\ e-mail: feng.liu.edu@gmail.com, \\ ORCID iD: (Dhttps://orcid.org/0000-0002-6716-6510
}

DOI: 10.5937/vojtehg69-29030; https://doi.org/10.5937/vojtehg69-29030

FIELD: Mathematics, Transport

ARTICLE TYPE: Original scientific paper

Abstract:

Introduction/purpose: Progress of science and development of new technologies brings increased everyday use of goods with potential human safety and health hazards. The aim of this paper was to select a model for training individuals who are to perform the function of dangerous goods transport advisors in the Ministry of Defense (MD) and the Serbian Armed Forces (SAF).

Methods: The problem was solved through the use of the AHP (Analytic Hierarchy Process) with ten subject-matter experts involved, who all contributed - within their individual competency level, with different individual weight of knowledge - to the final decision.

Results: The stability of the final decision was confirmed with a dynamic sensitivity analysis through the use of Expert Choice 2000 software. 
Connclusion: The results of the conducted research favored the model by which the training should be conducted relying on one's own resources.

Key words: model, training, transport safety advisor, dangerous goods.

\section{Introduction}

Industrial development contributed greatly to the development of transportation and through that to greater presence of dangerous goods in transportation activities. Every participant of the process of dangerous goods transport is exposed to the risk of possible accidents during the dangerous goods transport. Dangerous good transport accidents also present risk for individuals not directly involved in the process of goods transport, their material goods and the environment in which they live.

Dangerous goods transport in the armed forces is very pronounced given the fact that the majority of members of the armed forces are, by nature of the job, in everyday contact with some sort of dangerous goods. Precisely, this fact obliges armed forces to undertake many activities to prevent dangerous goods transport accidents.

Mode of transport and responsibilities of individuals involved in the transport of dangerous goods are prescribed through legal norms at national and international levels. Policy of dangerous goods transport in the MD and the SAF (Official Military Gazette, 8/2018) regulates transport of dangerous goods within the MD and the SAF, as well as by other armed forces or organisations which make use of the transportation infrastructure of the Republic of Serbia (RS), in accordance with a separate agreement. First and foremost, the mentioned policy is in accordance with the national Law of dangerous goods transport (Official Gazette of the RS, 95/2018) as well as with international agreements that regulate dangerous goods transport for different means of transportation.

For dangerous goods transport to function without problems and for it to be in accordance with regulations, a need arose for a person who has the knowledge of duties and responsibilities of all participants in the said process. That person is a Dangerous goods transport advisor.

Dangerous goods transport advisors are professionals in charge of full compliance with regulations during dangerous goods transportation activities performed by an organisation. This function can be executed only by individuals who attended prescribed training and are in possession of adequate certificates for the said function. 
According to the European Regulations concerning the international transport of dangerous goods by road ADR, a Dangerous goods transport advisor must be appointed within all organisations who participate in the process of dangerous goods transport or who are involved in other activities related to dangerous goods transport (packaging, filling, loading or unloading). For the mentioned positions, many individuals permanently hired by the organisation may be appointed, or the organisation could outsource and hire on contract when needed.

Duties of the Dangerous goods transport advisor are defined by the $A D R$ and are related to:

- monitoring of compliance with dangerous goods transport regulations,

- giving advice to decision makers within the organization for all activities related to dangerous goods transport, and

- creation of yearly reports about the activities and events related to dangerous goods transport.

The aim of this paper was to select a model for training individuals who are to perform functions of dangerous goods transport advisors in the MD and the SAF. The problem was solved through the use of the AHP (Analytic Hierarchy Process) with participation of multiple decision makers. The decision makers in the AHP evaluation of the said problem were members of the MD and the SAF, performing duties of organisation and conduct of dangerous goods transport.

The paper is composed of six sections, including Introduction and Conclusion. "Dangerous goods in transport", is the subject of the second section of this paper. The third section of the paper, entitled "AHP decisionmaking", describes the procedure for implementing the AHP at the individual and group level. The fourth section of the paper entitled "Formulation problem" describes the problem and presents the AHP hierarchy of decision-making problems. The "Results and discussion " are presented in the fifth section of the paper. The Conclusion section emphasizes the key benefits of the conducted research.

\section{Dangerous goods transport}

For a more accurate understanding of potential hazards associated with working with some substance, it is necessary to know and analyze a large number of physical and chemical properties of substances, as e.g. (Vidović et al, 2019): 
- type of danger,

- physical state,

- viscosity,

- boiling point,

- melting temperatures,

- density,

- the voltage of the steam,

- flammability temperature,

- auto-ignition temperature,

- limits of explosive mixtures,

- reactivity with respect to other substances, etc.

The term a "dangerous substance" refers to a substance with its physical-chemical characteristics, which are determined on the basis of the recognized and appropriate criteria. From the standpoint of chemistry, the mentioned term "dangerous substance" is not adequate to define the notion, but it would be the term "hazardous substance" (Jovanović et al, 2010).

Using the wrong term may lead to erroneous determination of the status of dangerous substances during the transport process, which directly affects both the application of appropriate recovery procedures in case of accidents, and the application of methods that are contrary to the international rules and obligations.

"Dangerous goods" refers to the keyword when the hazardous matter-substance is contained in an appropriate packaging - container or a vehicle during the transport process. There are specific criteria for potential risks from hazardous substances which determine the transport conditions (Jovanović et al, 2010).

According to the Rulebook of the Transport of Dangerous Goods in the Ministry of Defense and the Army of Serbia (Official Gazette 8/2018) and the Law of the Transport of Dangerous Goods (Official Gazette of the Republic of Serbia, 95/2018), dangerous goods are substances and articles forbidden from transport, i.e. allowed if transport is performed under international agreements and regulations for the transport of dangerous goods by the type of traffic (ADR, RID, ADN).

There are numerous examples of unprofessional and negligent treatment during handling (manipulating) in transport of dangerous goods, which have resulted in the suffering of people, property and environmental degradation (Pamučar et al, 2019; Pamučar, 2020). 
The consequences of road traffic accidents with vehicles transporting dangerous goods may also be such as to amount to a catastrophe. As e.g.:

- On $6^{\text {th }}$ December 1917, in Halifax (Nova Scotia), Figure 1, there was a collision due to the accident of the French ship "Mont Blanc" and the Norwegian ship "SS imo", in the access port and channel - Halifax, at a low speed of about $2.5 \mathrm{~km} / \mathrm{h}$. The Mont Blanc ship was carrying about 3.2 million pounds of picric acid and TNT for the needs of the French army in World War I. The effect of the explosion was in fragments of the ship, a shock wave and a tsunami 18 meters high, created by the explosion. The estimated temperature of the explosion was about $5000^{\circ}$ C. A pyrotrophic cloud rose to an altitude of about $3600 \mathrm{~m}$. The number of victims has never been precisely determined. It is believed that about 1,600 people were killed immediately, and about 400 succumbed to injuries, 9,000 were injured, 1,600 homes were destroyed in a series of fires and 12,000 homes were damaged. The industrial sector of the city was completely destroyed. The Halifax disaster was the unofficial start of systematic consideration of hazardous substances (Janković, 2016).

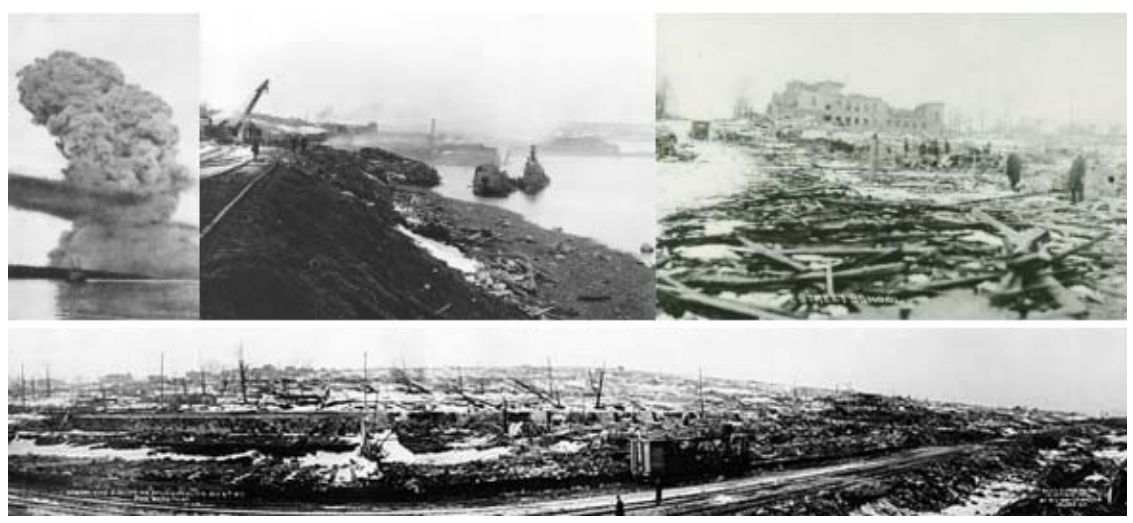

Figure 1 - Disaster in Halifax in 1917, the explosion of the ship and the consequences (Janković, 2016)

Puс. 1 - Взрыв в Галифаксе в 1917 году, кораблекрушение вследствие взрыва и его последствия (Janković, 2016)

Слика 1 - Катастрофа у Халифраксу 1917. године, последице експлозије брода (Janković, 2016) 
- In 1978, in Los Alfaques (Spain), a fuel tank was overloaded. Due to high heat and pressure, the tank exploded and the fuel caught fire, killing 216 people (Figure 2).

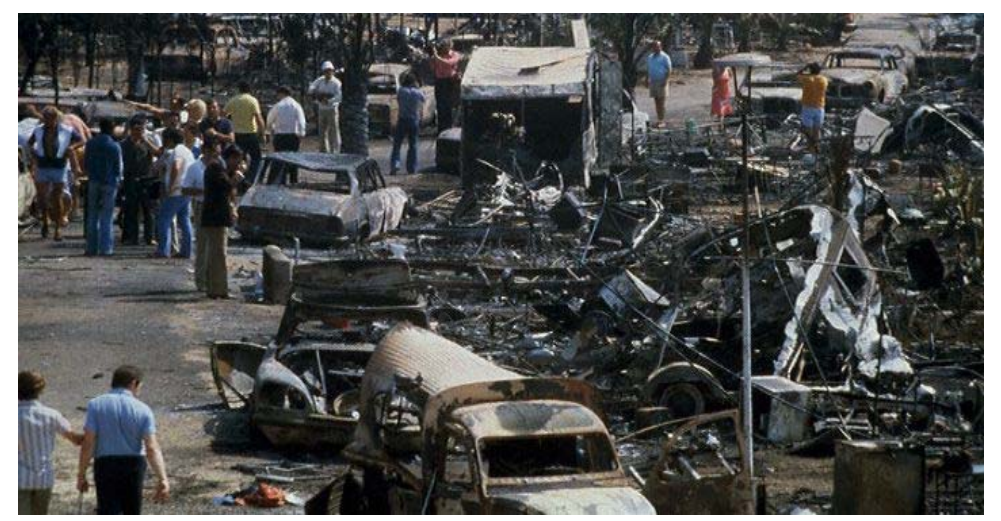

Figure 2 - Consequences of an accident on the way to Los Alfaques in 1978. Рис. 2 - Последствия ДТП в Лос-Альфакесе в 1978 году.

Слика 2 - Последице акцидента на путу у Лос Алфакуесу 1978. године

- On $12^{\text {th }}$ July 2012, in Okobie town in Nigeria, there was an explosion of a road tanker for gas transport (Figure 3). One hundred and twenty one people were killed in the accident and 75 were injured.
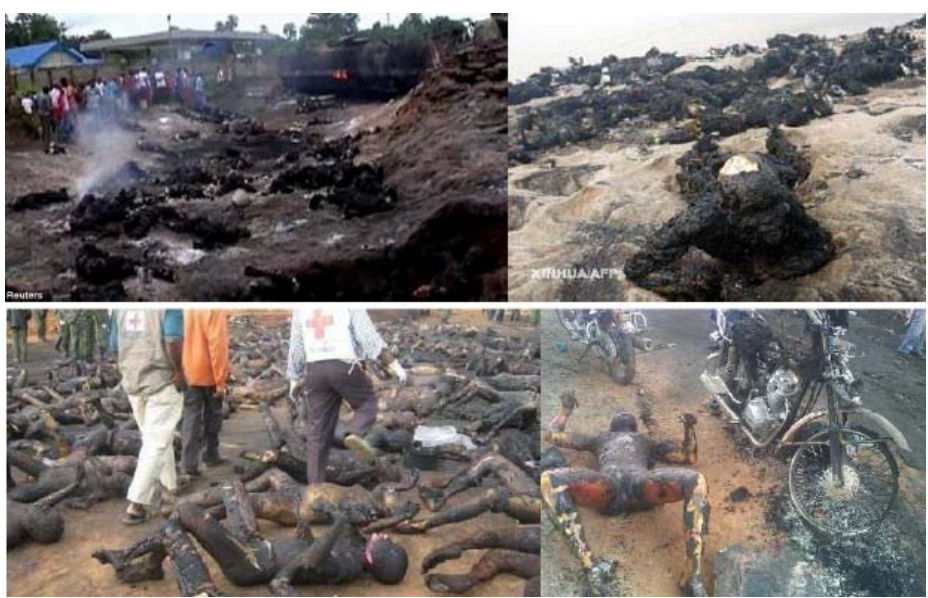

Figure 3-Consequences of the accident in Okobie-Nigeria, 12 $2^{\text {th }}$ July 2012. (Janković, 2016)

Puс. 3 - Последствия аварии в Окобие, Нигерия, 12 июля 2012 г. (Janković, 2016) Слика 3 - Последице акцидента у Окобие - Нигерија, 12. јул 2012. године (Janković, 2016) 
- In 1986, in Šabac, Serbia, a railroad tank carrying ammonia (NH3) hit an overpass from below. The valves got loose and the gas began to leak. Favorable wind and the timely intervention of specially trained workers prevented a more serious catastrophe.

To avoid this and similar situations and reduce risks to a minimum, it is necessary that all personnel who come into contact with dangerous goods, or all people involved, comply with regulations and guidelines that define the handling of dangerous goods, as well as be properly trained and prepared for their work.

On the basis of these problems, experts of the United Nations gave basic recommendations and guidelines for international agreements, i.e. procedures related to Conventions about different methods of transport of dangerous goods (Vidović et al, 2019; Jovanović et al, 2010; Janković, 2016; Jovanović, 2004; Petrović, 2004), Figure 4:

- European Agreement concerning the International Carriage of Dangerous Goods by Road (ADR),

- Regulations concerning the International Carriage of Dangerous Goods by Rail (RID),

- International Civil Aviation Organization - Tehnical Instructions for the Safe Transport of Dangerous Goods by Air (ICAO-TI),

- International Air Transport Association - Dangerous Goods Regulations (IATA-DGR),

- International Maritime Dangerous Goods-Code (IMDG-CODE), and

- European Agreement concerning the International Carriage of Dangerous Goods by Inland Waterways (ADN). 


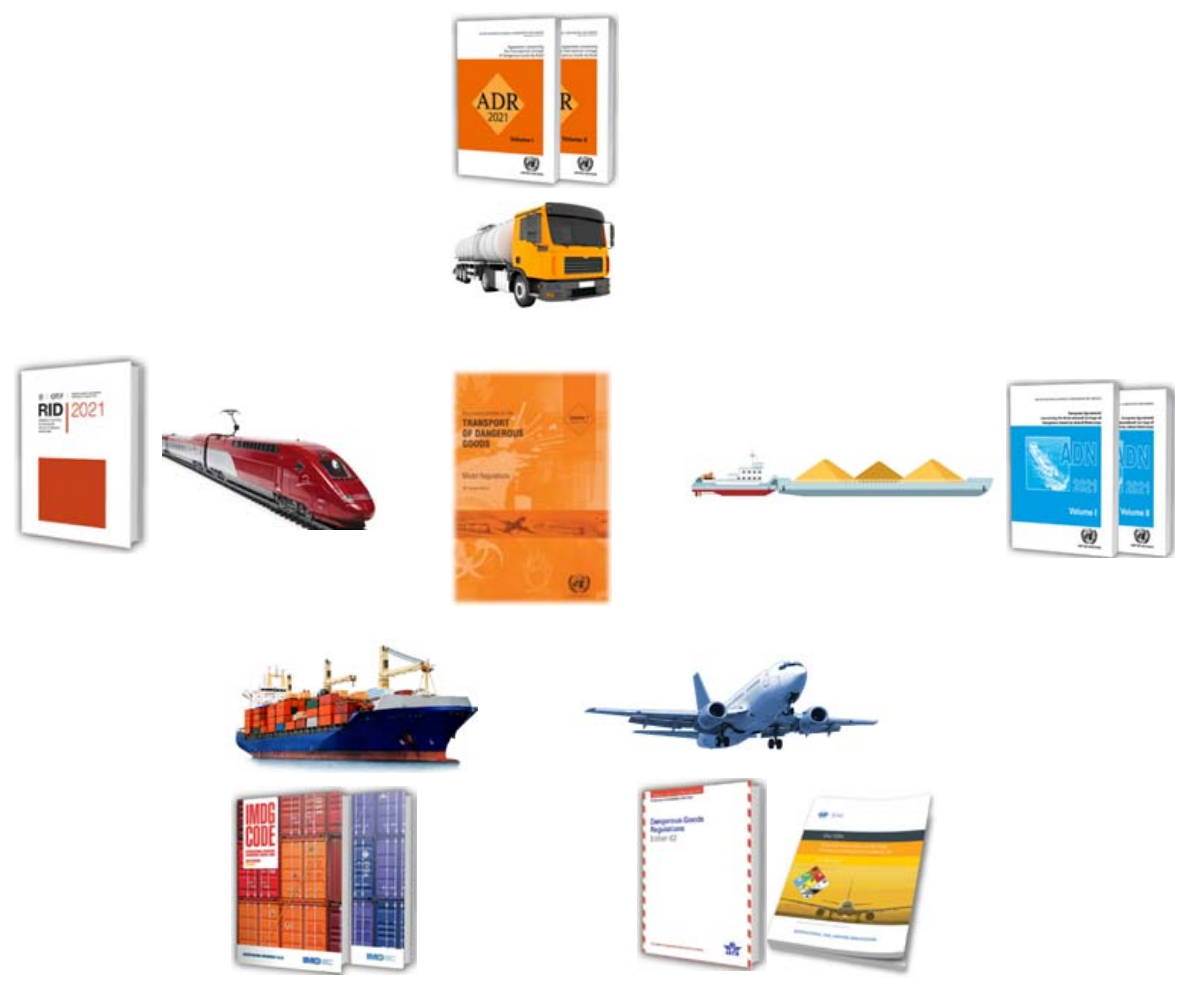

Figure 4 - International agreements on transport of dangerous goods Puc. 4 - Международные соглашения по перевозке опасных грузов Слика 4 - Међунардни споразуми о транспорту опасне робе

\section{AHP decision making}

The analytical hierarchical process (Saaty, 1980) is one of the most exploited methods for decision making when multiple criteria are considered. (Escobar, 2004; Vaidya \& Kumar, 2006; Altuzarra et al, 2007; Ho, 2008; Arnette et al, 2010; Subramanian \& Ramanathan, 2012; Bernasconi et al, 2014; Žižović \& Pamučar, 2019; Biswas et al, 2019; Stanković et al, 2019; Durmić et al, 2020; Janković \& Popović, 2019)

The method is "analytical" and "hierarchical" because decision making participants disassemble the root problem of decision making (the aim) to several decision-making elements and create hierarchical relations between them. The obtained hierarchy has a multilevel composition. At the top of the hierarchy is the aim, followed by the criteria at the next level and the alternatives at the bottom. This type of hierarchy 
presents the base problem of AHP decision making, but also reflects problems present in other hierarchy types, such as three-level hierarchy when a sub-criteria level is found between the criteria and the level of alternatives. Likewise, hierarchies with only two levels pose the same problems when only the aim and the alternative layers are found.

In order to determine relations between the AHP hierarchy elements, one has to compare groups of elements (couples) against the elements on the higher level of hierarchy. The comparison is done through rating and the use of the Saaty rating scale, as shown in Table 1.

Table 1 - Saaty rating scale

Таблица 1 - Оценочная шкала Саaти

Табела 1 - Скала оцена Saaty

$\begin{array}{ll}\text { Meaning Rating }\left(a_{i j}\right) & \text { Rat }\end{array}$

The absolute dominance of the element $\mathrm{i}$ over element $\mathrm{j} \quad 9$

Very strong element dominance $\mathrm{i}$ over element $\mathrm{j} \quad 7$

Strong element dominance $\mathrm{i}$ over element $\mathrm{j}$

Poor element dominance $i$ over element $j$

The same importance of element $i$ and element $j$

Poor element dominance $j$ over element $i \quad 1 / 3$

Strong element dominance $j$ over element $i \quad 1 / 5$

Very strong element dominance $j$ over element $i \quad 1 / 7$

Absolute dominance of the element $j$ over element $i \quad 1 / 9$

(Intermediates) (2,4,6,8)

Besides the Saaty rating scale, many other scales could be used, e.g. the Lootsma scale (Lootsma, 1988; Lootsma, 1990; Lootsma et al, 1990; Muravev \& Mijic, 2020; Ma et al, 2011). The Saaty rating scale is most common and its linear part is composed of whole number values (1 to 9 ), while the non linear part is composed of appropriate reciprocal values (1/1-9).

When a participant in the AHP, on a specific hierarchy level, rates semantically $n$ elements of that level against the elements of the higher level using the scale in Table 1 , its semantic rates from the left column are shown in equivalent number values from the right column and are entered in the square matrix $A$. The matrix is positive and reciprocal (symetrical in relation to the main diagonal), which means that the elements in the upper matrix triangle are reciprocal to the elements of the 
lower matrix triangle, while the elements on the main diagonal are equal to 1 ( $a_{i j}=1 / a_{j i}$, for each $i$ and $j ; a_{i i}=1$ for each $i$ ), Matrix 1 .

$$
A=\left[\begin{array}{cccc}
a_{11} & a_{12} & \ldots & a_{1 n} \\
a_{21} & a_{22} & \ldots & a_{2 n} \\
\ldots & \ldots & \ldots & \ldots \\
a_{n 1} & a_{n 2} & \ldots & a_{n n}
\end{array}\right]
$$

If the standard Saaty scale is used, then each of $a_{i j}$ can have one of 17 values from the discrete interval $[1 / 9,9]$. When filling in the matrix $A$, the transit rule should be followed $a_{i j}=a_{i k} * a_{k j}$ for every $i, j, k=1, \ldots, n$. Determining the weights of the compared elements based on the numerical values from the matrix is called prioritization. Prioritization is the process of determining the priority vector $w=\left(w_{1}, \ldots, w_{n}\right)^{T}$ from the matrix $A$, where every $w_{i} \succ 0$ implicates $\sum_{i=1}^{n} w_{i}=1$. There are multiple prioritisation methods, but the most used ones are the Additive normalisation method, the Eigenvector method, and the Logarithmic least squares method. (Blagojević, 2015; Blagojević et al, 2020).

Because of its simplicity and frequency of use, the additive normalization method was used in this paper (additive normalization method $-\mathrm{AN}$ ). In order to determine the vector of priorities $w$, it is sufficient to divide each element from a given column of the matrix $A$ by the sum of the elements of that column (normalization), then to compile the elements in each type, and finally to divide each resulting sum by the rank of the matrix $n$. This procedure is described by relations 2 and 3 :

$a_{i j}{ }^{\prime}=\sum_{i=1}^{n} a_{i j}, i j=1,2, \ldots, n$ 
$w_{i}=\frac{\sum_{j=1}^{n} a_{i j}}{n}, i=1,2, \ldots, n$

Based on the evaluation, the chosen method of prioritization determines the local weights of the decision elements, and the synthesis, i.e. the additive synthesis, ultimately determines the weights of the alternatives at the lowest level relative to the element at the highest level (goal), which determines ending individual decision making by the AHP. The additive synthesis is given by relation 4 :

$u_{i}=\sum_{j} w_{j} d_{i j}$

$-u_{i}$ - the final (global) priority of the alternative $i$,

$-w_{j}$ - weight of the alternative $j$,

- $d_{i j}$ - the local weight of the alternative $i$ relative to the criterion $j$.

In addition to the prioritization methods, one of the important features of the AHP is that it checks the consistency of decision maker evaluations at all levels of the hierarchy. For consistency checking (Saaty, 1977), the consistency ratio (CR) is suggested. It is used in AN prioritization methods. Calculating the consistency ratio includes two steps. The first step, the consistency index $(\mathrm{Cl})$ is calculated using relation 5:

$C I=\frac{\lambda_{\max }-n}{n-1}$

$-{ }^{n}$ - rank of the matrix,

$-\lambda_{\max }-$ the maximum eigenvalue of the comparison matrix.

The second step, the consistency ratio (CR) is calculated as the ratio of the consistency index $(\mathrm{Cl})$ and the random index $(\mathrm{RI})$, relation 6 :

$C R=\frac{C I}{R I}$ 
The random index is in direct relation to the rank of the matrix $(\mathrm{RI})$, Table 2.

Table 2 - Random index values

Таблица 2 - Значения случайного индекса

Табела 2 - Вредности случајног индекса

\begin{tabular}{ccccccccccc}
\hline $\mathrm{n}$ & 1 & 2 & 3 & 4 & 5 & 6 & 7 & 8 & 9 & 10 \\
$\mathrm{RI}$ & 0.00 & 0.00 & 0.52 & 0.89 & 1.11 & 1.25 & 1.35 & 1.40 & 1.45 & 1.49 \\
\hline
\end{tabular}

When the obtained $C R$ is $\leq 0.10$, it is considered that the participant of the AHP performed the analysis and evaluation in a consistent manner. (Jandrić \& Srđević, 2000; Kazimieras Zavadskas et al, 2020). In cases when CR is $>0.10$, the participant of the AHP should repeat the process and modify its evaluation process.

It is becoming a common practice in the creation of scientific papers where decision-making processes based on the opinions of single individuals are considered non-objective. That is why nowadays group decision making is more and more applied, i.e. decision making is based on opinions and suggestions of multiple participants in the process.

In the AHP, for the synthesis of separate decisions into a final, or group decision, multiple methods exist. Two most common methods for final decision making are (Ramanathan \& Ganesh, 1994; Forman \& Peniwati, 1998):

- Aggregation of Individual Priorities - AIP and

- Aggregation of Individual Judgments - AIJ.

To integrate individual decisions into group decisions, this paper uses the AIP method. Aggregation was perfomed using the Weight Arithmetic Mean Method-WAMM. The alternative $A_{i}$ and its weight value $w_{i}{ }^{(k)}$ (priority) for the $k$-th decision maker are given. If all the members of the $\operatorname{group}(g)$ are assigned appropriate weight values $\alpha_{k}$, the weight arithmetic mean is:

$w_{i}^{(g)}=\sum_{k=1}^{m} w_{i}^{(k)} \alpha_{k}$

$-w_{i}^{(g)}-$ final (composite) priority of the alternative $A_{i}$,

$-m-$ number of decision makers (group members). 
By assumption, the individual weights of the group members $\alpha_{k}$ are previously additively normalized $\sum_{k=1}^{m} \alpha_{k}=1$. A final additive normalization of the priorities of all alternatives is needed.

The sensitivity analysis of the final decision is a very important characteristic of the AHP. It is conducted to determine if the changes of the entry parameters influence the score list of alternatives in the final decision. Multiple software solutions exist for the sensitivity analysis and Expert Choice is one of the most used ones.

If the changes of the entry parameters for $5 \%$ in all combinations do not cause changes in the score list of alternatives, the final AHP decision is considered stable (Hot, 2014).

\section{Problem formulation}

The training of Dangerous goods transport advisors for the MD and the SAF is held in certified civilian institutions. Such a training model presents problems that affect functioning of transportation units within the MD and the SAF, among which the most important ones are:

- Mutual dependency between the training plan terms and the capability of civilian training institutions,

- Weak teritorial availabilty of civilian institutions for dangerous goods transport advisor training outside regional hubs,

- Training costs, and

- Personal costs for trainees.

That said, in order to analyse the existing approach to training Dangerous goods transport advisors within the MD and the SAF, a group of experts in the field of dangerous goods transport, made of ten transportation officers from the MD and the SAF, was surveyed.

The first part of the survey allowed the experts to give their opinions on possible training models for Dangerous goods transport advisors of the MD and the SAF. The second part of the survey guided the experts in determining the criteria based on which the training model was to be selected. The process used in decision making about the training model was the analytic hierarchy process (AHP).

The setup of the AHP hierarchy for deciding on the model of training candidates for the function of Dangerous goods transportation advisors is shown in Figure 5. 


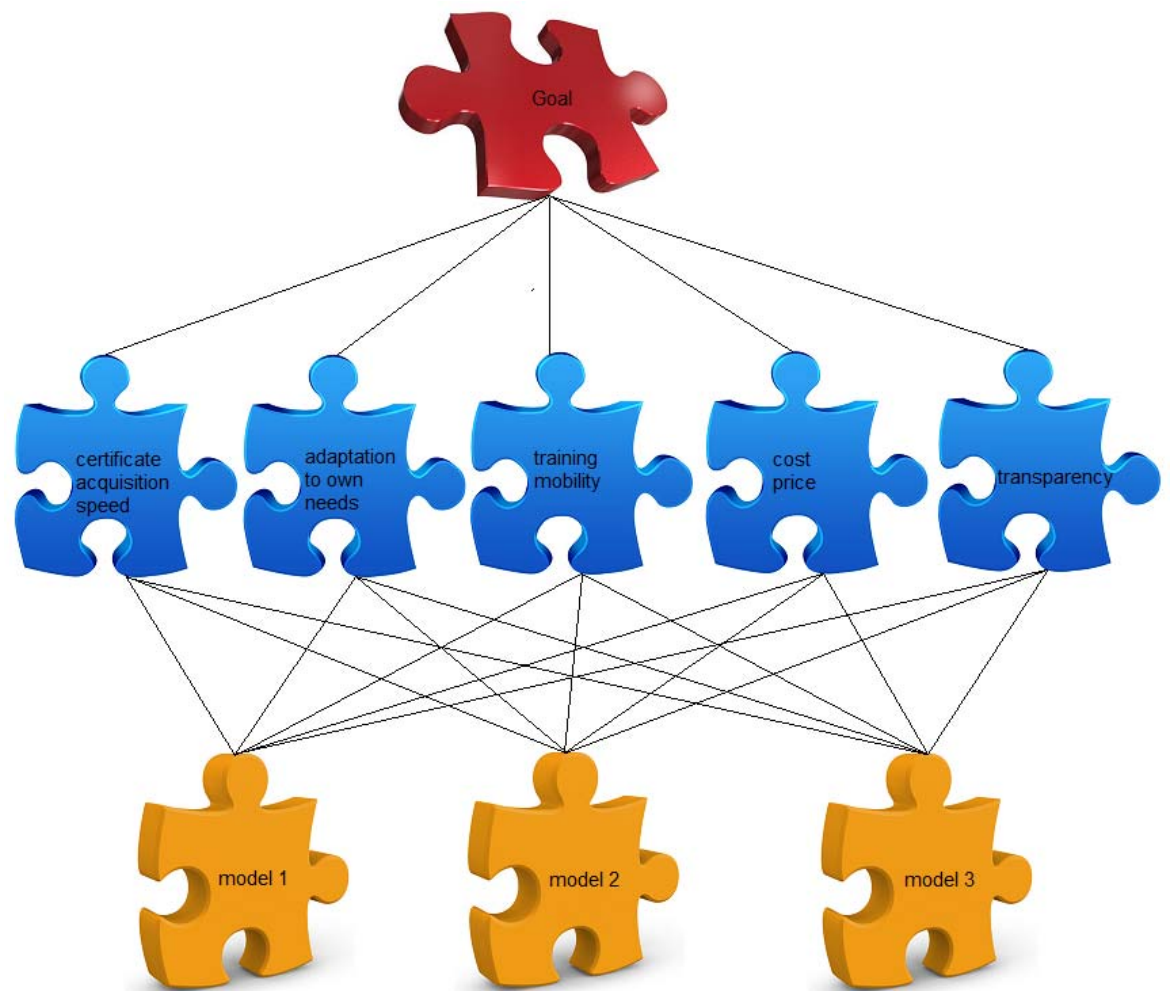

Figure 5 - Setting up the AHP hierarchy

Puc. 5 - Настройка иерархии AHP

Слика 5 - Поставка AHP хијерархије

Figure 5 shows a standard decision making problem where the aim (the training model) is at the top of the hierarchy. On the next level, there are criteria (certificate acquisition speed, adaptation to own needs, training mobility, cost price, transparency). Models which should be used in training Dangerous goods transportation advisors are represented by alternatives in the AHP hierarchy, and are located at the bottom level:

- model 1 - Model in which both training and certification would be conducted in accordance with the present practice, i.e. relying on the civilian sector,

- model 2 - Model in which training would be conducted within armed forces and certification would be conducted in the civilian sector, 
- model 3 - Model in which both training and certification would be conducted within armed forces units using own resources.

Competency assessment of expert group members was conducted according to the approach which Djorovic (2003) recommends for competency assessment of transportation support experts, which accounts for three assessment aspects:

- Objective assessment,

- Assessment of the source of the argument, and

- Subjective assessment of the expert.

A dettailed overview of the above mentioned approach to the competency assessment of the experts is shown in Djorovic (2003) and Lukovac (2016). The results of the competency assessment process of the experts in this research have confirmed their competencies for research participation, see Table 3.

Table 3 - Competence assessment

Таблица 3 - Оценка компетентности

Табела 3 - Оцена компетентности

\begin{tabular}{cl}
\hline Experts & Expertise assessment \\
\hline 1. & 0.6675 \\
2. & 0.67 \\
3. & 0.5413 \\
4. & 0.69 \\
5. & 0.4988 \\
6. & 0.525 \\
7. & 0.4763 \\
8. & 0.5063 \\
9. & 0.64 \\
10. & 0.57 \\
\hline Group assessment & 0.57852 \\
\hline
\end{tabular}

After being introduced with the AHP methods, subject-matter experts were given forms to evaluate the elements of the AHP hierarchy for the choice of a model for training candidates for the function of Dangerous goods transport advisors. Figure 6 shows a completed form for the AHP evaluation of one of the members of the expert group. 


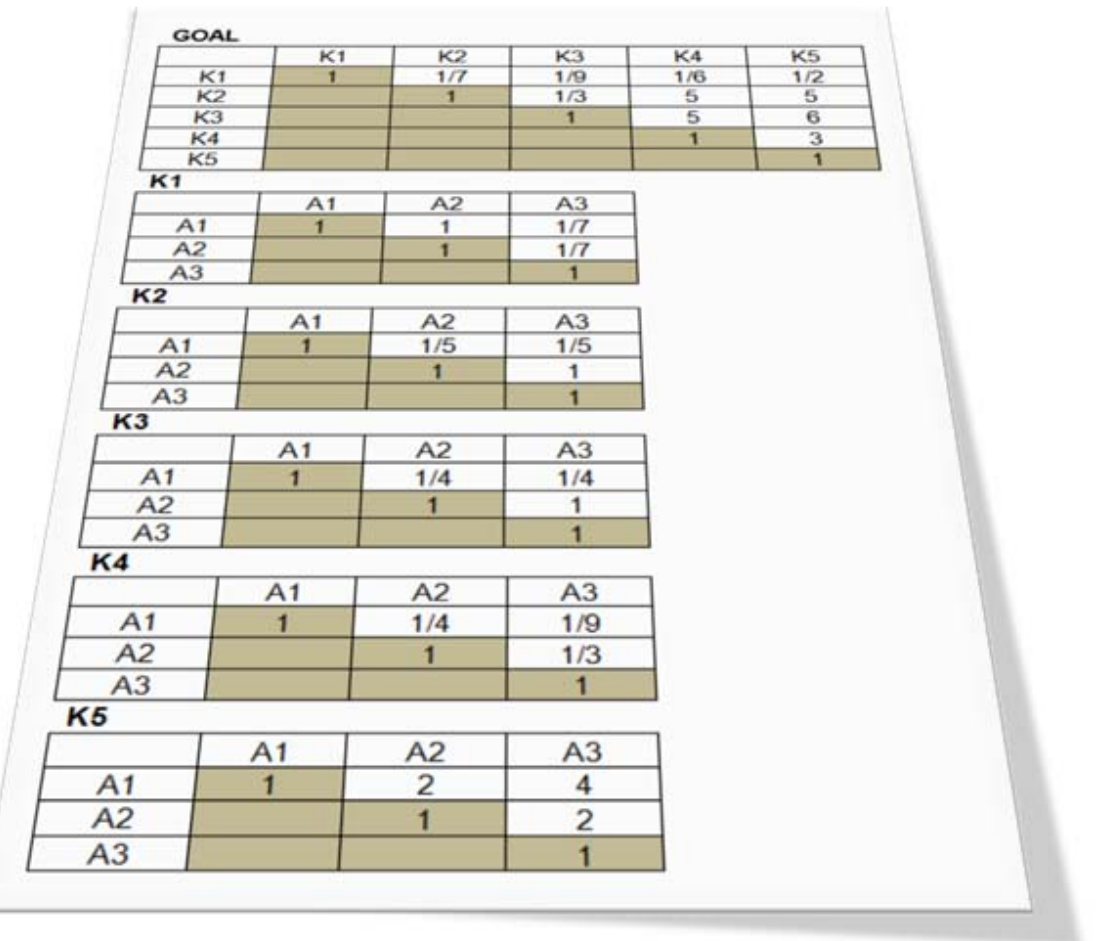

Figure 6-AHP evaluation form

Puc. 6 - Форма оценки АНP

Слика 6 - Образац за АНP вредновање

\section{Results and discussion}

Processing of the gathered forms for the AHP evaluation was done by the use of Expert Choice 2000 (EC 2000) software, which yielded the results shown in Table 4.

Compiling individual expert decisions into a final decision was done through compiling individual priorities according to the relations shown in Equation 7. In final decision making, Table 5, the experts used the weighted normalised values of their evaluated competences. 
Table 4 - Expert decisions Таблица 4 - Экспертные решения Табела 4 - Експертске одлуке

\begin{tabular}{clll}
\hline Experts & $\mathrm{A} 1$ & $\mathrm{~A} 2$ & $\mathrm{~A} 3$ \\
\hline 1. & 0.12 & 0.42 & 0.46 \\
2. & 0.12 & 0.42 & 0.46 \\
3. & 0.18 & 0.17 & 0.65 \\
4. & 0.52 & 0.35 & 0.13 \\
5. & 0.52 & 0.31 & 0.17 \\
6. & 0.67 & 0.13 & 0.21 \\
7. & 0.27 & 0.37 & 0.36 \\
8. & 0.18 & 0.17 & 0.65 \\
9. & 0.12 & 0.42 & 0.46 \\
10. & 0.27 & 0.37 & 0.36 \\
\hline
\end{tabular}

Table 5 - Final decision Таблица 5 - Окончательное решение Табела 5 - Коначна одлука

\begin{tabular}{lll}
\hline Models & Importance & Rang \\
\hline A1 & 0.29 & 3 \\
A2 & 0.32 & 2 \\
A3 & 0.39 & 1 \\
\hline
\end{tabular}

Figure 7 holds the results of the final decision.

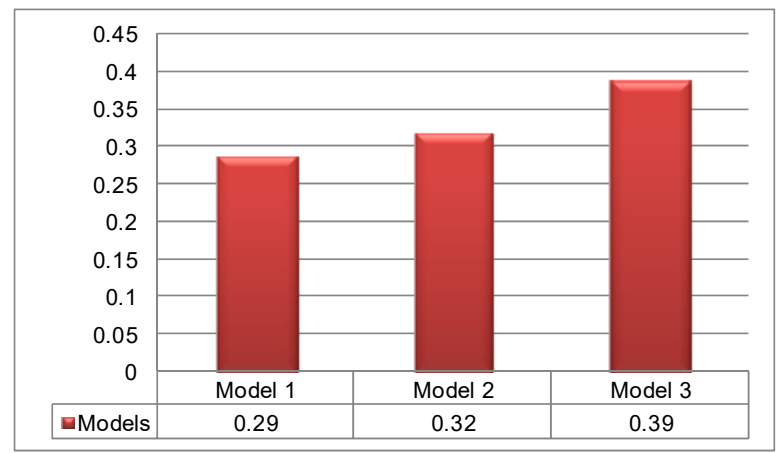

Figure 7 - Graphic representation of the final decision

Puc. 7 - Графрическое изображение окончательного решения Слика 7 - Графрички приказ коначне одлуке 
Figure 7 shows that the decision makers favored "model 3". A sensitivity analysis of the final decision made by the members of the expert group was conducted with the use of EC 2000 software. Noting that the changing of the initial entry parameters by $5 \%$ did not cause the alternative range to change, the final decision made by the members of the experts group can be considered stable.

In the end, based on the conducted AHP evaluation, it can be concluded that training and certification of dangerous goods advisors in the MD and the SAF should be conducted relying on own resources.

\section{Conclusions}

Dangerous goods transport, based on the means of transport, necessitates full compliance of regulations at all levels (including organisational, national and international). Prevention of accidents which may occur during dangerous goods transport is a duty for all participants. The decision on the model of training candidates for the function of Dangerous goods transport advisors stems from multivariate analysis and participation of more experts with adequate competencies. For the purpose of this paper, the AHP was used in a group context. Managing the group decision process can be done in many different ways. One of them is favoring decisions of specific participants through the process of evaluation of participants. To make group decision more objective, individual participants of this AHP evaluation had their decisions weighted with the use of normalization of their competencies. The decision obtained after the AHP evaluation process points out that the model for training candidates for the function of Dangerous goods transport advisors and certification which should be used is the one where only the resources of the MD and the SAF were used, without external assistance.

\section{References}

Altuzarra, A., Moreno-Jimenez, J.M. \& Salvador, M.A. 2007. Bayesian priorization procedure for AHP-group decision making. European Journal of Operational Research, 182(1), pp.367-382. Available at: https://doi.org/10.1016/j.ejor.2006.07.025

Arnette, A., Zobel, C., Bosch, D., Pease, J. \& Metcalfe, T. 2010. Stakeholder ranking of watershed goals with the vector analytic hierarchy process: Effects of participant grouping scenarios. Environmental Modelling \& Software, 25(11), pp.1459-1469.

Available

at:

https://doi.org/10.1016/j.envsoft.2009.10.009. 
Bernasconi, M., Choirat, C. \& Seri, R. 2014. Empirical properties of group preference aggregation methods employed in AHP: Theory and evidence. European Journal of Operational Research, 232(3), pp.584-592. Available at: https://doi.org/10.1016/j.ejor.2013.06.014.

Biswas, S., Bandyopadhyay, G., Guha, B. \& Bhattacharjee, M. 2019. An ensemble approach for portfolio selection in a multi-criteria decision making framework. Decision Making: Applications in Management and Engineering, 2(2), pp.138-158 [online]. Available at: https://www.dmame.rabek.org/index.php/dmame/article/view/51 [Accessed: 20 August 2021].

Blagojević, A., Vesković, S., Kasalica, S., Gojić, A. \& Allamani, A. 2020. The application of the fuzzy AHP and DEA for measuring the efficiency of freight transport railway undertakings. Operational Research in Engineering Sciences: Theory and Applications, 3(2), pp.1-23 [online]. Available at: https://www.oresta.rabek.org/index.php/oresta/article/view/52 [Accessed: 20 August 2021].

Blagojević, B. 2015. Minimization of distance between group and individualdecisions using intelligent stochastic algorithms for waterand agricultural management. Ph.D. thesis. Novi Sad, Serbia: University of Novi Sad, Faculty of Agriculture (in Serbian) [online]. Available at: https://nardus.mpn.gov.rs/handle/123456789/8802?locale-attribute=en [Accessed: 20 August 2021].

Durmić, E., Stević, Ž., Chatterjee, P., Vasiljević, M. \& Tomašević, M. 2020. Sustainable supplier selection using combined FUCOM - Rough SAW model. Reports in Mechanical Engineering, 1(1), pp.34-43 [online]. Available at: https://frontpres.rabek.org/index.php/asd/article/view/4 [Accessed: 20 August 2021].

Escobar, M.T., Aguarón, J. \& Moreno-Jiménez, J.M. 2004. A note on AHP group consistency for the row geometric mean priorisation procedure. European Journal of Operational Research, 153(2), pp.318-322. Available at: https://doi.org/10.1016/S0377-2217(03)00154-1.

Forman, E. \& Peniwati, K. 1998. Aggregating individual judgments and priorities with the analytic hierarchy process. European Journal of Operational Research, 108(1), pp.165-169. Available at: https://doi.org/10.1016/S03772217(97)00244-0.

Ho, W. 2008. Integrated analytic hierarchy process and its applications-A literature review. European Journal of Operational Research, 186(1), pp.211228. Available at: https://doi.org/10.1016/j.ejor.2007.01.004.

Hot, I. 2014. Management of conceptual designs creation in field of infrastructure by use of multi-criteria analysis. Ph.D. thes. Novi Sad, Serbia: University of Novi Sad, Faculty of Technical Science (in Serbian) [online]. Available at: https://nardus.mpn.gov.rs/handle/123456789/1901 [Accessed: 20 August 2021]. 
Jandrić, Z. \& Srđević, B. 2000. Analitički hijerarhijski proces kao podrška odlučivanju u vodoprivredi. Vodoprivreda, 32, pp.186-188, pp.327-334 (in Serbian).

Janković, A. \& Popović, M. 2019. Methods for assigning weights to decision makers in group AHP decision-making. Decision Making: Applicatons in Management and Engineering, 2(1), pp.147-165 [online]. Available at: https://www.dmame.rabek.org/index.php/dmame/article/view/35 [Accessed: 20 August 2021].

Janković, Z. 2016. The Development of Model for the Dangerous Goods Risk Calculation Inlogistics Systems. Ph.D. thes. Novi Sad, Serbia: University of Novi Sad, Faculty of Technical Science (in Serbian) [online]. Available at: https://nardus.mpn.gov.rs/handle/123456789/6681 [Accessed: 20 August 2021].

Jovanović, V.D. 2004. Transport opasnih materija. Belgrade: University of Belgrade, Faculty of Transport and Traffic Engineering (in Serbian). ISBN: 867395-179-8.

Jovanović, V.D., Mladenović, D.M. \& Milovanović, B.M. \& 2010. Transport opasne robe u drumskom saobraćaju. Belgrade: University of Belgrade, Faculty of Transport and Traffic Engineering (in Serbian). ISBN: 978-86-7395-266-6.

Kazimieras Zavadskas, E., Turskis, Z., Stević, Ž. \& Mardani, A. 2020. Modelling procedure for the selection of steel pipes supplier by applying fuzzy AHP method. Operational Research in Engineering Sciences: Theory and Applications, 3(2), pp.39-53 [online]. Available at: https://oresta.rabek.org/index.php/oresta/article/view/53 [Accessed: 20 August 2021].

Lootsma, F.A. 1988. Numerical Scaling of Human Judgement in PairwiseComparison Methods for Fuzzy Multi-Criteria Decision Analysis. In: Mitra, G., Greenberg, H.J., Lootsma, F.A., Rijkaert, M.J., Zimmermann, H.J. (Eds.) Mathematical Models for Decision Support. NATO ASI Series (Series F: Computer and Systems Sciences), 48. Berlin, Heidelberg: Springer. Available at: https://doi.org/10.1007/978-3-642-83555-1_3.

Lootsma, F.A. 1990. The french and the american school in multi-criteria decision analysis. RAIRO - Operations Research - Recherche Opérationnelle, 24(3), pp.263-285 [online]. Available at: http://www.numdam.org/item/RO_1990_24_3_263_0/ 6681 [Accessed: 20 August 2021].

Lootsma, F.A., Mensch, T.C.A. \& Vos, F.A. 1990. Multi-criteria analysis and budget reallocation in long-term research planning. European Journal of Operational Research, 47(3), pp.293-305. Available at: https://doi.org/10.1016/0377-2217(90)90216-X.

Ma, Z., Shao, C., Ma, S. \& Ye, Z. 2011. Constructing road safety performance indicators using Fuzzy Delphi Method and Grey Delphi Method. Expert Systems with Applications, 38 (3), pp.1509-1514. Available at: https://doi.org/10.1016/j.eswa.2010.07.062. 
Muravev, D. \& Mijic, N. 2020. A Novel Integrated Provider Selection Multicriteria Model: The BWM-MABAC Model. Decision Making: Applications in Management and Engineering, 3(1), pp.60-78 [online]. Available at: https://dmame.rabek.org/index.php/dmame/article/view/57 [Accessed: 20 August 2021].

Pamučar, D. 2020. Normalized weighted Geometric Dombi Bonferoni Mean Operator with interval grey numbers: Application in multicriteria decision making. Reports in Mechanical Engineering, 1(1), pp.44-52 [online]. Available at: https://www.frontpres.rabek.org/index.php/asd/article/view/5 [Accessed: 20 August 2021].

Pamučar, D., Sremac, S., Stević, Ž., Ćirović, G. \& Tomić, D. 2019. New multi-criteria LNN WASPAS model for evaluating the work of advisors in the transport of hazardous goods. Neural Computing and Applications, 31(9), pp.5045-5068. Available at: https://doi.org/10.1007/s00521-018-03997-7.

Petrović, Lj. 2004. Transport opasne robe u drumskom saobraćaju Upoznavanje restrukturiranog ADR-a. Belgrade: Trigon inženjering (in Serbian).

Ramanathan, R. \& Ganesh, L.S. 1994. Group preference aggregation methods employed in AHP: an evaluation and an intrinsic process for deriving members' weightages. European Journal of Operational Research, 79(2), pp.249-265. Available at: https://doi.org/10.1016/0377-2217(94)90356-5.

Saaty, T.L. 1977. A scaling method for priorities in hierarchical structures. Journal of Mathematical Psychology, 15(3), pp.234-281. Available at: https://doi.org/10.1016/0022-2496(77)90033-5.

Stanković, M., Gladović, P. \& Popović, V. 2019. Determining the importance of the criteria of traffic accessibility using fuzzy AHP and rough AHP method. Decision Making: Applications in Management and Engineering, 2(1), pp.86-104 [online]. Available at: https://dmame.rabek.org/index.php/dmame/article/view/27 [Accessed: 20 August 2021].

Subramanian, N. \& Ramanathan, R. 2012. A review of applications of Analytic Hierarchy Process in operations management. International Journal of Production Economics, 138(2), pp.215-241. Available at: https://doi.org/10.1016/j.ijpe.2012.03.036.

Vaidya, O.S. \& Kumar, S. 2006. Analytic hierarchy process: An overview of applications. European Journal of Operational Research, 169(1), pp.1-29. Available at: https://doi.org/10.1016/j.ejor.2004.04.028.

Vidović, M., Radivojević, G. \& Ratković, B. 2019. Roba u logističkim procesima. Belgrade: University of Belgrade, Faculty of Transport and Traffic Engineering (in Serbian). ISBN: 978-86-7395-398-4.

Žižović, M. \& Pamučar, D. 2019. New model for determining criteria weights: Level Based Weight Assessment (LBWA) model. Decision Making: Applications in Management and Engineering, 2(2), pp.126-137 [online]. Available at: https://www.dmame.rabek.org/index.php/dmame/article/view/48 [Accessed: 20 August 2021]. 
МНОГОКРИТЕРИАЛЬНЫЙ ПОДХОД К ВЫБОРУ МОДЕЛИ ОБУЧЕНИЯ СОВЕТНИКОВ ПО ОПАСНЫМ ГРУЗАМ В МИНИСТЕРСТВЕ ОБОРОНЫ И ВООРУЖЁННЫХ СИЛАХ РЕСПУБЛИКИ СЕРБИЯ

Веско М. Луковаца , Светлана Р. Зелич-Дракулич

Лазар М. Томичв

а Университет обороны в г. Белград, Военная академия, департамент логистики, г. Белград, Республика Сербия, корреспондент

${ }^{\sigma}$ Вооружённые Силы Республики Сербия, Сухопутные войска,

Учебно-тренировочное командование, г. Белград, Республика Сербия

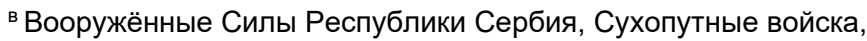
Третья бригада, г. Ниш, Республика Сербия

г Университет Чжецзян Ванли в г. Нинбо, факультет управления бизнесом, г. Нинбо, Китайская Народная Республика

РУБРИКА ГРНТИ: 27.00.00 МАТЕМАТИКА:

27.47.19 Исследование операций,

28.00.00 КИБЕРНЕТИКА:

28.17.31 Моделирование процессов управления, 73.00.00 ТРАНСПОРТ:

73.47.12 Организация управления и автоматизированные системы управления транспортом

ВИД СТАТЬИ: оригинальная научная статья

Резюме:

Введение/цель: Научные достижения $и$ развитие новых технологий способствуют повседневному потреблению нарастающего количества товаров, которые могут вызвать неблагоприятные последствия для безопасности и здоровья человека. Цель данной статьи заключается в представлении модели, в соответствии с которой должно проводиться обучение лиц, занимающих должность советника по безопасности перевозки опасных грузов в Министерстве обороны (МO) u Вооруженных силах Республики Сербия (ВСРС).

Meтоды: Проблема решалась с помощью AHP (Analytic Hierarchy Process), в процессе решения участвовали десять экспертов, которые в соответствии с их оцененной компетенцией внесли каждый свой индивидуальный вклад в окончательное решение задачи.

Результаты: Стабильность окончательного решения подтверждена динамическим анализом чувствительности с помощью программы Expert Choice 2000. 
Выводы: Результаты проведенного исследования свидетельствуют о преимуществах модели, согласно которой обучение должно проводиться исходя из собственных возможностей.

Ключевые слова: модель, обучение, советник по транспортной безопасности, опасные грузы.

ВИШЕКРИТЕРИЈУМСКИ ПРИСТУП ИЗБОРУ МОДЕЛА ОБУКЕ

САВЕТНИКА ЗА БЕЗБЕДНОСТ ТРАНСПОРТА ОПАСНЕ РОБЕ У МИНИСТАРСТВУ ОДБРАНЕ И ВОЈСЦИ СРБИЈЕ

Веско М. Луковац ${ }^{\text {, }}$ Светлана Р. Зељић-Дракулићб,

Лазар М. Томићв

а Универзитет одбране у Београду, Војна академија, Катедра логистике, Београд, Република Србија, аутор за преписку

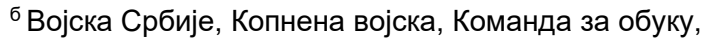
Београд, Република Србија

в Војска Србије, Копнена војска, 3. бригада, Ниш, Република Србија

г Универзитет „Зхејианг Ванли”, Факултет за бизнис,

Нингбо, Народна Република Кина

ОБЛАСТ: математика, транспорт

ВРСТА ЧЛАНКА: оригинални научни рад

Сажетак:

Увод/циљ: Напредак науке и развој нових технологија доприноси свакодневној употреби све већег броја роба које могу изазвати нежељене последице по безбедност и здравља људи. Циљ овог рада јесте избор модела по којем би требало вршити оспособљавање лица за обављање функције саветника за безбедност транспорта таквих врста роба у Министарству одбране (MO) и Војсци Србије (BC) .

Memode: Проблем је решаван помоћу AHP (Analytic Hierarchy Process) у којем су учествовала десеторица екперата, а који су захваљујући својој компетентности допринели коначној одлуци.

Резултати: Стабилност коначне одлуке потврђена је динамичком анализом осетљивости помоћу coфmвера Expert Choice 2000.

Закључак: Резултати спроведеног истраживања фраворизовали су модел по којем би обуку требало спроводити ослањајући се на сопствене капацитете.

Кључне речи: модел, обука, саветник за безбедност транспорта, опасна роба. 
Paper received on / Дата получения работы / Датум пријема чланка: 29.08.2021. Manuscript corrections submitted on / Дата получения исправленной версии работы / Датум достављања исправки рукописа: 18.10.2021.

Paper accepted for publishing on / Дата окончательного согласования работы / Датум коначног прихватања чланка за објављивање: 20.10.2021.

(C) 2021 The Authors. Published by Vojnotehnički glasnik / Military Technical Courier (www.vtg.mod.gov.rs, втг.мо.упр.срб). This article is an open access article distributed under the terms and conditions of the Creative Commons Attribution license (http://creativecommons.org/licenses/by/3.0/rs/).

() 2021 Авторы. Опубликовано в «Военно-технический вестник / Vojnotehnički glasnik / Military Technical Courier» (www.vtg.mod.gov.rs, втг.мо.упр.срб). Данная статья в открытом доступе и распространяется в соответствии с лицензией «Creative Commons» (http://creativecommons.org/licenses/by/3.0/rs/).

(c) 2021 Аутори. Објавио Војнотехнички гласник / Vojnotehnički glasnik / Military Technical Courier (www.vtg.mod.gov.rs, втг.мо.упр.срб). Ово је чланак отвореног приступа и дистрибуира се у складу са Creative Commons лиценцом (http://creativecommons.org/licenses/by/3.0/rs/). 